\title{
Birinci Basamak Sağlık Hizmetlerinde Hasta Memnuniyeti: İstanbul İlinde Bir Araştırma
}

Service Patient Satisfaction in Primary Health Care: A Study in Istanbul Province

\author{
Seda ÜSTÜN ${ }^{1}$, Esra Çiğdem CEZLAN ${ }^{2}$
}

\begin{abstract}
ÖZ
Sağlık çalışanlarının hastalara yönelik tutumları hasta memnuniyetini etkileyen önemli bir etmendir. $\mathrm{Bu}$ çalışmanın amacı; birinci basamak aile hekimliği merkezlerine başvuran hastaların memnuniyet düzeylerini ölçmektir. Çalışmanın evrenini Haziran Temmuz 2017 tarihleri arasında İstanbul İli Avrupa Yerleşkesi'nde bulunan Gaziosmanpaşa, Eyüp, Fatih ve Anadolu Yerleşkesi'nde bulunan Beykoz, Kadıköy, Üsküdar ilçelerindeki 6 aile hekimliği merkezine başvuran ve araştırmaya katılmayı kabul eden, 18 yaş ve üstü 400 hasta oluşturmuştur. Kesitsel nitelikte olan bu çalışmada yüz yüze anket uygulanmıştır. Araştırmada kullanılan veri toplama aracı European Patients Evaluate General/Family Practice (EUROPEP) ölçeği, European Working Party on Quality in Family Practice (EQuiP) tarafindan 1999 yılında geliştirilmiş ve 2002 yılında Aktürk ve arkadaşları tarafından Türkçe'ye çevrilmiştir. Çalışmada, analitik ve grafiksel yöntemler kullanılarak normal dağılıma uygunluk kontrolü yapıldıktan sonra tanımlayıcı istatistikler, bağımsız örneklem $\mathrm{t}$ test ve tek yönlü ANOVA kullanılmıştır. Elde edilen veriler IBM SPSS 22.0 programı ile analiz edilmiş, sonuçlar \%5 anlamlılık seviyesinde yorumlanmıştır. Araştırma sonucunda memnuniyet ve memnuniyetsizlik düzeyleri ölçülerek, hastaların aile hekimlerinin iletişiminden beklentileri ve açığa çıkan sorunları saptanmıştır. Elde edilen sonuçlara göre kayıt ve bilgilerinizi gizli tutması sorusu en yüksek ortalamaya $4,14 \pm 0,85$ sahip soru olarak bulunurken, en düşük ortalamaya $3,11 \pm 1,50$ sahip soru doktorunuza telefonla ulaşabilmeniz olarak bulunmuştur. Birinci basamak aile hekimliği merkezlerine başvuran hastaların sosyodemografik özelliklerinden yaş, eğitim ve yerleşke ortalamalarına göre anlamlı bir farklılık olduğu bulunmuştur $(\mathrm{p}<0,05)$. Sonuç olarak; Avrupa Yerleşkesi'nde aile hekimliği hizmeti alan hastaların memnuniyet oranının, Anadolu Yerleşkesi'ndeki hasta memnuniyet oranından daha yüksek olduğu saptanmıştır.
\end{abstract}

Anahtar Kelimeler: Aile hekimliği, EUROPEP Ölçeği, Hasta memnuniyeti

\begin{abstract}
Healthcare professionals' attitudes towards patients are important factors affecting patient satisfaction. The aim of this study is; Primary care family medicine centers. The study consists of 400 patients, with the age above 18, who applied to 6 family medicine centers in Beykoz, Kadıköy, Üsküdar districts in Gaziosmanpaşa, Eyüp, Fatih and Anadolu Campus in Istanbul European Campus between June and July 2017 and accepted to participate in the study. This cross-sectional was applied to the face-to-face. The data collection tool used in the study, the European Patients Evaluate General/ Family Practice (EUROPEP) scale, was translated into Turkish by the European Working Party on Quality in Family Practice (EQuiP) in 1999 and 2002 by Aktürk et al. In the study, statistics, independent samples t test and one-way ANOVA were used after analytical and graphical monitor normal distribution was checked. The obtained data were analyzed with IBM SPSS 22.0 program, the results were interpreted as $5 \%$ significance. By measuring the satisfaction and dissatisfaction levels of the patients in their experiences, patients' occuring problems and the expectations from their clinicians are determined. According to the results obtained, the question of keeping records and information confidential is found as the question with the highest average of $4.14 \pm 0.85$, while the question with the lowest average is $3.11 \pm 1.50$ as you can reach your doctor by phone. The patient who applied to primary care family medicine centers had a history according to his sociodemographic characteristics, age, education and campus averages $(p<0.05)$. As a result; It has been determined that the satisfaction rate of family medicine service providers in the European Campus is higher than the satisfaction rate in the Anatolian Campus.
\end{abstract}

Keywords: Family medicine, EUROPEP Scale, Patient satisfaction

\footnotetext{
*Bu çalı̧̧ma yüksek lisans tezinden türetilmiştir. İstanbul Medipol Üniversitesi Girişimsel Olmayan Klinik Araştırmalar Etiği Kurulu Başkanlığı'ndan etik izin (Karar No:13.05.2016-2016/255) alınmıştır.

${ }^{1}$ Seda ÜSTÜN, Sağlı Yönetimi, Prof. Dr. Cemil Taşcıoğlu Șehir Hastanesi Veri Giris ve Kontrol İşletmenliği, sedaustnn@gmail.com, ORCID: 0000-0002-9109-9100

${ }_{2}^{2}$ Dr. Öğr. Üyesi, Esra Çiğdem CEZLAN, Sağlık Yönetimi, İstanbul Medipol Üniversitesi Sağlık Bilimleri Yüksekokulu Sağlı Yönetimi, eccezlan@medipol.edu.tr, ORCID: 0000-0002-9238 4907
} 


\section{GíRiş}

Demografik değişiklikler, tıptaki gelişmeler, hastalıkların yapısındaki değişiklikler, ölüm nedenlerinin farklılaşması, ortalama insan ömrünün uzamasıyla birlikte yaşlı nüfusun ve kronik hastalıkların artışı, hastaların gereksinim ve beklentileri gibi değişikliklerden dolayı bireyleri yakından takip edebilecek bir aile hekimine ihtiyaç duyulduğunu görmek mümkündür. ${ }^{1-3}$

DSÖ’ye göre aile hekimliği, "kendi başlarına ya da diğer sağlık çalışanları ile birlikte ekip halinde ilk başvuruda verilen hizmeti sunan ve direkt olarak ulaşılabilen kişi olarak; sağlığı iyileştirici, hastalıklardan koruyucu, tedavi edici, rehabilite edici ve destekleyici sağlık hizmetlerini bir bütün olarak sunar". 4

Dünya Aile Hekimleri Örgütü WONCA aile hekimliği kavramını, "kendine özgü eğitim içeriği, araştırması, kanıt temeli ve klinik uygulaması olan akademik ve bilimsel bir disiplin ve birinci basamak yönelimli klinik bir uzmanlıktır" şeklinde tanımlar ve aile hekimliği disiplininin "birinci basamak yönetimi, kişi merkezli bakım, özgün problem çözme becerileri, kapsamlı yaklaşım, toplum yönelimli olma, bütüncül yaklaşım-modelleme" olmak üzere altı çekirdek yeterlikte toplandığını belirtir. ${ }^{1}$

Birinci basamak sağlık hizmetlerinin sunumunda önemli bir rol üstlenen aile hekimleri; anne karnındaki fetüsten, ailenin en yaşlisına kadar tüm aile bireylerinin sağlından sorumludur. ${ }^{5}$ Aile hekimi; yaş, cinsiyet, 1rk, din, dil, hastalık ayrımı yapmaksızın her bireye sürekli ve kapsamlı olarak sağlık hizmeti sunar. ${ }^{1}$

Aile hekimliği merkezleri, hastaların erişebileceği bir konumda olması dolayısıyla sağlık hizmetlerinde hastaların hekime ulaştı̆̆1 ilk basamağı oluşturmaktadır. Aile hekimi, hizmet sunduğu toplumu tanır, kendisine kayitlı olan bireyleri hem hasta oldukları anda hem de sağlıklı anlarında sürekli olarak takip eder. ${ }^{6}$ Sadece bireyleri değil aileleriyle ve çevreyle olan ilişkilerini de bütüncül bir yaklaşımla değerlendirir. Bireylerin ve ailelerinin, sağlık durumlarını ve yaşama koşullarını göz önünde bulundurur. En uygun tan 1 ve tedavi yöntemini hastasının da etkin katılımını sağlayarak uygular ve gerekli sağlık eğitimlerini verir. ${ }^{5}$

Aile hekimliğinin sağlık hizmetlerine ilk giriş noktası olma özelliğiyle birlikte diğer sağlı kuruluşlarına geçişte kap1 tutucu (gatekeeping) olma özelliği de vardır. ${ }^{7}$ Doğru bir şekilde işleyen sevk sistemiyle sağlık sorunlarının büyük bir çoğunluğu aile hekimliği tarafından çözümlenerek diğer sağlık kuruluşlarında oluşacak yığılmalar engellenir ve kaynakların verimli olarak kullanılması sağlanır. ${ }^{8}$

Doğumda beklenen yaşam beklentisinin artmas1 ve insan ömrünün uzamasının sonucunda; yaşlı nüfus artmakta ve buna bağlı olarak kronik hastalıklarında arttığ görülmektedir. Kronik hastalıklar, hastanın yaşam kalitesini ciddi oranda düşürebilen, sürekli bir bakım ve tedavi gerektirdiğinden hem bireysel hem de toplumsal düzeyde iyi yönetilmesi geren hastalıklardır. ${ }^{3}$ Büyük çoğunluğu ev ortamında yaşayan yaşlı nüfusun sağlık ihtiyaçları, evlerine yakın bir konumda olan ve onları tanıyan bir aile hekiminin varlığıla daha etkin bir şekilde kontrol altında olacaktır. ${ }^{5}$

Hasta memnuniyeti; hastanın hizmeti almadan önceki beklentileri ile aldıktan sonraki algısı arasındaki fark olarak sağlık hizmetlerinin kalitesini gösteren temel bir ölçüt şeklinde tanımlanır. ${ }^{9}$ Beklentilerini tamamen karşılayan veya üstündeki hizmetler hasta tarafindan olumlu, beklentilerin altındaki hizmetler ise olumsuz olarak değerlendirilerek hasta memnuniyeti belirlenir. ${ }^{10}$ Hasta memnuniyetini etkileyen faktörler ise şunlardır;

- Hastaya ilişkin faktörler; hastaların beş temel psikolojik (kişilik, algılama, motivasyon, tutum, yenilikçilik düzeyi) ve üç 
temel sosyokültürel (sosyal sınıf, kültür, aile ilişkileri) özellikleri bulunur ve bu özelliklere göre hasta memnuniyeti şekillenir. ${ }^{11}$

- Hizmet sunanlara ilişkin faktörler; hekim başta olmak üzere tüm sağlık hizmeti sunanların hastalara gösterdikleri ilgi, anlayış, tebessüm, saygılı olma gibi davranışlar tıbbi bilgi birikimle birleşince hastaların sağlık sorununu daha rahat anlamasına olanak sağlayarak tedaviye hastanın da katılımını arttırır. ${ }^{12}$

- Çevresel ya da kurumsal faktörler; hasta memnuniyetine etki eden çevresel ya da kurumsal faktörler; ulaşılabilirlik, aydınlatma, 1Sı, havalandırma, gürültü, temizlik, sağlık hizmeti sunulan binanın dış görünümü, bürokrasi ve ücret gibi faktörlerdir. ${ }^{13,14}$

Hasta memnuniyetini ölçme ve değerlendirme yöntemleri; niteliksel kalitatif- yöntemler (yönetsel gözlemler, personel geri bildirimleri ve çalışma ekipleri, odak grup görüşmeleri, yorum kartları, standart -simüle- hasta yöntemi) ve niceliksel -kantitatif- yöntemler (anket yöntemi, telefon görüşmeleri) olmak üzere ikiye ayrılır. ${ }^{10} \mathrm{En}$ çok kullanılan yöntem anket yöntemidir. ${ }^{15}$

Kişi odaklı olan aile hekimliği kendisine kayıtlı olan kişilerin ihtiyaç ve isteklerini de göz önünde bulundurur. Kaliteli sağlik hizmetlerinin göstergesi olan hasta memnuniyeti aile hekimliği içinde oldukça önemlidir. ${ }^{15}$ Hastanın memnuniyeti arttıkça; hekimin uyarılarına ve önerilerine uyma olasılığı artacak, sevk oranları azalacaktır. ${ }^{16,}$ 17

İyi bir hasta hekim ilişkisi, hasta memnuniyetinin temelini oluşturur. Aile hekimi ve hastanın arasındaki sürekli iletişim hasta memnuniyetinin güçlenmesini sağlayarak bireylerin tedavi süreçlerine aktif olarak katılmalarını sağlar. ${ }^{16}$ Hastalıkların erken süreçte saptanmalarını ve önlenmesini sağlayarak sağlığın arttırılmasını teşvik eder. ${ }^{17}$

Sağlik hizmeti sunan her kurumun olduğu gibi aile hekimliğinin de girdisi ve çıktısı insandır. Sağlık sorunları nedeniyle kırılgan ve beklentileri yüksek olan insanlarla iletişim kurmak özen ister. $^{3}$ Bir süreç olan hasta hekim görüşmesinde, hekim hastasını tanır, geliş nedenini anlamaya çalışır, sağlık sorununu anlamaya ve hastanın bu sağllk sorununa nasıl yaklaştığını kavramaya çalışır. Tüm bu sürecin sonunda ise hastaya en uygun tanıyı koyarak tedaviye başlanır. ${ }^{18}$

Hekimin etkili bir görüşme yapabilmesi için tecrübesi kadar iletişim ve sorun çözme yeteneği de önemlidir. Hekim hastanın sırdaşıdır ve hekimin iletişim yeteneği ne kadar iyiyse hasta o kadar hekimine güvenecek, anlatmaktan çekindiği sağlik problemlerini de rahatlıkla anlatacaktır. ${ }^{15}$

Uygulanabilir ve güçlü özellikteki birinci basamak sağlık hizmetine sahip bir toplumun sağlık ihtiyaçları her zaman en iyi şekilde karşılanacaktır. Birinci basamak sağlık hizmetlerinde önemli bir görev üslenen aile hekimliğinin geliştirilmesi ve sistemin hizmet alan kişiler tarafından nasıl algılandığının belirlenmesi için hasta memnuniyetinin ölçülmesi gerekmektedir. ${ }^{19}$, 20

$\mathrm{Bu}$ nedenle araștırmamız, hastaların aile hekimliği hizmetlerine olan memnuniyetlerini ölçerek, hastaların aile hekimlerinin klinik davranışı ve hizmet organizasyonu hakkında görüşlerini belirlemek, aile hekimliği hizmetlerinin geliştirilmesi gereken yönlerinin saptanmasına katkı sağlayabileceği düşünülerek planlanmıştır.

$\mathrm{Bu}$ araştırma, hastaların aile hekimliği hizmetlerinden duydukları memnuniyet oranlarının demografik özelliklere (yaş, cinsiyet, medeni durum, öğrenim durumu) ve İstanbul ili Avrupa ve Anadolu Yerleşkelerine göre memnuniyet düzeyinin değişip değişmediğini belirlemek bakımından önem taşımaktadır.

İstanbul ili Avrupa Yerleşkesi'nde Gaziosmanpaşa, Eyüp, Fatih ve Anadolu Yerleşkesi'nde Beykoz, Kadıköy, Üsküdar ilçelerindeki aile hekimliği hizmetlerine başvuran hastaların memnuniyetlerinin ölçülmesi amaçlanmıştır. Böylelikle açığa çıkan sorunlar belirlenerek sorunlara yönelik çözüm önerileri sunulmuştur. 


\section{MATERYAL VE METOT}

\section{Araştırmanın Türü}

Araştırma türü, tanımlayıcı türde kesitsel bir çalışmadır.

\section{Araştırmanın Yeri ve Zamanı}

$\mathrm{Bu}$ araştırma İstanbul İli Avrupa Yerleşkesi'nde bulunan Gaziosmanpaşa, Eyüp, Fatih ve Anadolu Yerleşkesi'nde bulunan Beykoz, Kadıköy, Üsküdar ilçelerindeki 6 aile hekimliği merkezlerinde yapılmıştır. Araştırmanın anket uygulama tarihi ise 01.06.2017-31.08.2017 tarihleri arasıdır.

\section{Araştırmanın Evren ve Örneklemi}

Araştırmanın evrenini İstanbul ilinde 6 ayrı farklı aile hekimliğinden hizmet alan hastalar oluşturmaktadır. Araştırmanın örneklemini 2017 Haziran-Temmuz tarihleri arasında İstanbul İli Avrupa Yerleşkesi'nde bulunan Gaziosmanpaşa, Eyüp, Fatih ve Anadolu Yerleşkesi'nde bulunan Beykoz, Kadıköy, Üsküdar ilçelerindeki 6 farklı aile hekimliği merkezlerinden hizmet alan 18 yaş ve üstü 400 kişi oluşturmaktadır. Uygulanan anketler yüz yüze uygulanmış olup katılım için gönüllülük esas alınmıştır.

\section{Veri Toplama Araçları}

Araştırmada veri toplama aracı olarak kullanilan European Patients Evaluate General/Family Practice (EUROPEP) ölçeği Dünya Aile Hekimleri Birliği (WONCA) Avrupa örgütünün bir alt birimi olan European Working Party on Quality in Family Practice (EQuiP) tarafından 1999 yılında geliştirilmiş olup 2002 yılında Aktürk ve arkadaşları tarafından Türkçe'ye çevrilmiş ve Türkiye genelinde de hasta memnuniyetini ölçmek için kullanılan anket formu kullanılmıştır. Hastalardan kendilerinin dolduracağ ay içerisinde en sık başvurdukları hekimlerini ve aile sağlığı merkezini değerlendirecekleri, 23 sorudan oluşan bir ölçekle değerlendirmeleri istenir. ${ }^{21}$ Anket, iki kısımdan oluşmaktadır. Anketin ilk kısmı demografik bilgiler (5 soru) ikinci kısmı ise EUROPEP ölçeğinden oluşmaktadır (23 soru).

6 şıklı Likert ölçeği kullanılan ölçekte sorulardan (1- Çok kötü, 2-kötü, 3-orta, 4-iyi, 5-mükemmel, 6-uygun değil/ilgisiz) ilk 16 soru klinik davranışı, geriye kalan sorular ise hizmet organizasyonunu ölçmektedir. ${ }^{21}$

\section{Problem Cümlesi}

Aile hekimliğinden hizmet alan hastaların aldıkları sağlık hizmetinden duydukları memnuniyet düzeylerinin ne ölçüde karşılandığı, aile hekimlerinin iletişiminden ne bekledikleri ve hizmet sonrasi hangi sorunların açığa çıktığı sorularını hizmet alınan coğrafi bölgeler ve demografik özellikler bakımından karşılaştırmalar yaparak tespit etmek çalışmanın temel problem cümlesidir. Ölçülen memnuniyet düzeylerinin sonucuna göre aile hekimliği hizmetlerinin hangi süreçlerinde geliştirilmesi gerektiği, iyileştirme yapılmasin saptanması ise ikincil problem cümlesidir.

\section{Araştırmanın Etik Yönü}

Araştırmanın yürütülebilmesi için İstanbul Medipol Üniversitesi Girişimsel Olmayan Klinik Araştırmalar Etiği Kurulu Başkanlığı'ndan etik izin (Karar No:13.05.2016-2016/255) alınmıștır. Araştırmanın başlığı etik kurul kararı ile E10840098-772.02-1473 makale için kullanılan başlık olarak değişikliğge uğramıştır.

Araştırmanın gerçekleştirildiği İstanbul İli 6 Aile Hekimliği Merkezi'nden Halk Sağlik Müdürlüğü'nden Kurum izni (12.06.2017 tarih ve E-67350377-604.02-E.555 say1) alınmıştır.

\section{Verilerin Analizi}

Anket yöntemiyle elde edilen verilerin bilgisayar ortamında IBM SPSS (Statistical Package For Social Sciences) 22.0 programına girişi sağlanmıştır. SPSS programına girilen verilere ait tanımlayıcı istatistikler ortalama, medyan, yüzde, standart sapma ile analiz edilmiştir. Verilerin normal dağılıma uygunluğu grafiksel yöntemler ve Kolmogrov ve Smirnov testi ile analiz edilmiş olup verilerin karşılaştırılmasında bağımsız örneklem $t$ testi, tek yönlü ANOVA testlerinden yararlanılmıştır. Sonuçlar $\mathrm{p}<0,05$ anlamlılık seviyesinde değerlendirilmiştir. 


\section{Araştırmanın Kısıtlılıkları}

Araştırma İstanbul ili Avrupa Yerleşkesi'nde Gaziosmanpaşa, Eyüp, Fatih ve Anadolu Yerleşkesi'nde Beykoz, Kadıköy, Üsküdar ilçelerindeki aile sağlı̆̆ merkezlerinden Haziran-Temmuz 2017 tarihleri arasında sağlık hizmeti almaya gelen ve çalışmaya katılmayı kabul eden 18 yaş ve üstü hastalar üzerinde yapılmıştır.

\section{BULGULAR VE TARTIŞMA}

Araştırma anketlerine katılanların demografik özelliklerinin sayısal ve yüzdesel dağılımları Tablo 1'de gösterilmiştir. Araştırmaya katılanların 95'i (\%23,8) 45-54 yaş aralığında, 205'i (\%51,3) kadın, 253'ü $(\% 63,3)$ evli, 131'i $(\% 32,8)$ lise mezunu, 80 'i (\%20) Gaziosmanpaşa'ya bağlı aile sağlığı merkezlerinden birine kayıtlıdır.

Tablo 1. Demografik Özelliklere Göre Araştırma Grubunun Sayısal ve Yüzdesel Dağılımı

\begin{tabular}{|c|c|c|}
\hline $\begin{array}{l}\text { Demografik } \\
\text { Özellikler }\end{array}$ & Sayı (n) & Yüzde (\%) \\
\hline \multicolumn{3}{|l|}{ Yaş } \\
\hline $18-24$ yaş & 88 & 22,0 \\
\hline $25-34$ yaş & 83 & 20,8 \\
\hline $35-44$ yaş & 91 & 22,8 \\
\hline $45-54$ yaş & 95 & 23,8 \\
\hline 55 yaş ve üstü & 43 & 10,8 \\
\hline \multicolumn{3}{|l|}{ Cinsiyet } \\
\hline Kadın & 205 & 51,3 \\
\hline Erkek & 195 & 48,8 \\
\hline \multicolumn{3}{|l|}{ Medeni Durum } \\
\hline Bekar & 147 & 36,8 \\
\hline Evli & 253 & 63,3 \\
\hline \multicolumn{3}{|c|}{ Öğrenim Durumu } \\
\hline İlkokul & 52 & 13,0 \\
\hline Ortaokul & 39 & 9,8 \\
\hline Lise & 131 & 32,8 \\
\hline Ön Lisans & 70 & 17,5 \\
\hline Lisans & 93 & 23,3 \\
\hline Lisans üstü & 15 & 3,8 \\
\hline \multicolumn{3}{|c|}{ Kayıtlı Olunan Aile Sağlığı Merkezi } \\
\hline Gaziosmanpaşa & 80 & 20,0 \\
\hline Eyüp & 70 & 17,5 \\
\hline Fatih & 60 & 15,0 \\
\hline Beykoz & 65 & 16,3 \\
\hline Üsküdar & 60 & 15,0 \\
\hline Kadıköy & 65 & 16,3 \\
\hline
\end{tabular}

Çalışmaya verilen cevapların tanımlayıcı istatistikleri Tablo 2'de gösterilmiştir. Tablo 2'de Katılımcıların en yüksek puan aldığ1 sorular kayıt ve bilgilerinizi gizli tutmas1 $4,14 \pm 0,85$, sizi dinlemesi $3,74 \pm 0,92$ ve işini tam yapması $3,70 \pm 0,91$, en düşük aldığ puanlar ise doktorunuza telefonla ulaşabilmeniz $3,11 \pm 1,50$, bekleme odasında harcadığınız zaman $3,15 \pm 1,04$ ve önceki görüşmelerde yaptıklarını ve söylediklerini

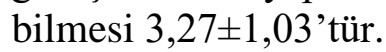

Ölçeğe ait güvenilirlik katsayısı olan Cronbach's Alpha $(\alpha) \quad 0,959$ olarak bulunmuştur. $\mathrm{Bu}$ değer " $0,80 \leq \alpha \leq 1,00$ " aralığında yer aldı ̆ı için ölçek "yüksek derecede güvenilir" bulunmuştur. ${ }^{22}$

Tablo 2. Çalışmaya Verilen Cevapların Tanımlayıcı İstatistikleri

\begin{tabular}{|c|c|c|c|c|}
\hline Soru & $\mathbf{N}$ & $\overline{\mathbf{x}}$ & Medyan & Ss \\
\hline $\begin{array}{l}\text { Kayit ve bilgilerinizi } \\
\text { gizli tutmas1 }\end{array}$ & 400 & 4,14 & 4,00 & 0,85 \\
\hline Sizi dinlemesi & 400 & 3,74 & 4,00 & 0,92 \\
\hline İşini tam yapması & 400 & 3,70 & 4,00 & 0,91 \\
\hline Sizi muayene etmesi & 400 & 3,66 & 4,00 & 0,96 \\
\hline $\begin{array}{l}\text { Sorunlarınızı ona } \\
\text { söylemenizi } \\
\text { kolaylaştırması }\end{array}$ & 400 & 3,63 & 4,00 & 0,86 \\
\hline $\begin{array}{l}\text { Şikayetleriniz veya } \\
\text { hastalığınız hakkında } \\
\text { istediğiniz bilgileri } \\
\text { vermesi }\end{array}$ & 400 & 3,60 & 4,00 & 0,93 \\
\hline $\begin{array}{l}\text { Günlük ihtiyaçlarınızı } \\
\text { görecek kadar iyi } \\
\text { hissetmenize yardım } \\
\text { etmesi }\end{array}$ & 400 & 3,58 & 4,00 & 0,93 \\
\hline $\begin{array}{l}\text { Size uygun zamanlara } \\
\text { randevu alabilmeniz }\end{array}$ & 400 & 3,56 & 4,00 & 1,07 \\
\hline $\begin{array}{l}\text { Şikayetlerinizi çabuk } \\
\text { geçirmesi }\end{array}$ & 400 & 3,55 & 4,00 & 0,91 \\
\hline $\begin{array}{l}\text { Görüşmeler sırasında } \\
\text { yeterli zamanınızın } \\
\text { olduğunu } \\
\text { hissettirmesi }\end{array}$ & 400 & 3,54 & 4,00 & 0,88 \\
\hline $\begin{array}{l}\text { Sizin özel } \\
\text { durumunuzla } \\
\text { ilgilenmesi }\end{array}$ & 400 & 3,54 & 4,00 & 0,95 \\
\hline $\begin{array}{l}\text { Tibbi bakımınızla } \\
\text { ilgili kararlara sizi de } \\
\text { katması }\end{array}$ & 400 & 3,54 & 4,00 & 0,92 \\
\hline $\begin{array}{l}\text { Test ve tedavilerin } \\
\text { amaçlarını açılaması }\end{array}$ & 400 & 3,50 & 4,00 & 0,96 \\
\hline $\begin{array}{l}\text { Tavsiyelerine } \\
\text { uymanızın önemini } \\
\text { kavramanıza } \\
\text { yardımc1 olmas1 }\end{array}$ & 400 & 3,46 & 4,00 & 0,90 \\
\hline
\end{tabular}




\section{Tablo 2. Devamı}

\begin{tabular}{|c|c|c|c|c|}
\hline $\begin{array}{l}\text { Sağlık durumunuza } \\
\text { bağlı duygusal } \\
\text { sorunlarla başa } \\
\text { çıkmanıza yardımcı } \\
\text { olması }\end{array}$ & 400 & 3,45 & 4,00 & 1,03 \\
\hline $\begin{array}{l}\text { Uzmana ya da } \\
\text { hastaneye sevkten } \\
\text { beklemeniz } \\
\text { gerekenler konusunda } \\
\text { sizi hazırlamas1 }\end{array}$ & 400 & 3,45 & 3,00 & 1,13 \\
\hline $\begin{array}{l}\text { Acil sağlık sorunları } \\
\text { için hızlı hizmet } \\
\text { sunması }\end{array}$ & 400 & 3,42 & 3,00 & 1,14 \\
\hline $\begin{array}{l}\text { Hastalıklardan } \\
\text { korunmanız için } \\
\text { sunduğu hizmetler } \\
\text { (sağlık taraması, } \\
\text { sağlık kontrolü, } \\
\text { aş1lama gibi) }\end{array}$ & 400 & 3,41 & 3,00 & 1,12 \\
\hline $\begin{array}{l}\text { Doktor dış1 } \\
\text { personelin yardımı }\end{array}$ & 400 & 3,33 & 3,00 & 1,15 \\
\hline $\begin{array}{l}\text { Muayenehaneye } \\
\text { telefonla } \\
\text { ulaşabilmeniz }\end{array}$ & 400 & 3,33 & 3,00 & 1,27 \\
\hline $\begin{array}{l}\text { Önceki görüşmelerde } \\
\text { yaptıklarını ve } \\
\text { söylediklerini bilmesi }\end{array}$ & 400 & 3,27 & 3,00 & 1,03 \\
\hline
\end{tabular}

Not: $\bar{x}=$ Ortalama, Ss = Standart Sapma

Hasta memnuniyetinin demografik özellikler ve yerleşkeye göre karşılaştırılması tablosu Tablo 3'e göre;

Birinci basamak sağlık hizmeti veren aile sağlığı merkezlerine başvuran hastaların memnuniyet düzeyleri cinsiyet açısından incelendiğinde ortalamalarına göre anlamlı bir farklilık bulunmamıştır $\quad(\mathrm{t}=0,604$; $\mathrm{p}=0,546$ ).

Yaş grup ortalamalarına göre birinci basamak sağlık hizmeti veren aile sağlı̆̆ merkezlerine başvuran hastaların memnuniyet düzeylerine bakıldığında gruplar arasında anlamlı farklılık bulunmuştur $(\mathrm{F}=2,602 ; \quad \mathrm{p}=0,036)$. Gruplar arasındaki farklılık incelendiğinde, bu farklılığın 45-54 yaş ortalamasına sahip olan kişilerin aile sağlığı merkezlerinden duyduğu memnuniyetin, 55 yaş ve üstü olan bireylerin aile sağlığı merkezlerinden duyduğu memnuniyetten istatistiksel olarak düşük olmasından kaynaklandığı sonucuna ulaşılmıştır $(\mathrm{p}<0,05)$.
Birinci basamak sağlık hizmeti veren aile sağlığı merkezlerine başvuran hastaların memnuniyet düzeyleri medeni duruma göre incelendiğinde grup ortalamalarına göre anlamlı bir farklılık bulunmamıştır $(\mathrm{t}=-0,636$; $\mathrm{p}=0,525)$.

Eğitim durumu ortalamalarına göre birinci basamak sağlık hizmeti veren aile sağlığı merkezlerine başvuran hastaların memnuniyet düzeylerine bakıldığında gruplar arasında anlamlı farklilık bulunmuştur $(\mathrm{F}=2,655 ; \quad \mathrm{p}=0,033)$. Gruplar arasındaki farklılık incelendiğinde, bu farklılığın ilkokul mezunlarının aile sağlığı merkezlerinden duyduğu memnuniyet ortalamasının lisans ve lisansüstü mezunlarının aile sağlığ1 merkezlerinden duyduğu memnuniyet ortalamasından istatistiksel olarak yüksek olmasindan kaynaklandığı sonucuna ulaşılmıştır $(\mathrm{p}<0,05)$.

Aile sağlığı merkezi ortalamalarına göre birinci basamak sağlik hizmeti veren aile sağlığı merkezlerine başvuran hastaların memnuniyet düzeyleri incelendiğinde gruplar arasında anlamlı farklılık bulunmuştur $(\mathrm{F}=5,675 ; \quad \mathrm{p}=0,04)$. Gruplar arasındaki farklılığa göre, Kadıköy'de ikamet eden kişilerin aile sağlığ memnuniyetin, diğer bölgelerde (Gaziosmanpaşa, Eyüp, Fatih, Beykoz, Üsküdar) ikamet eden kişilerin aile sağlı̆̆1 merkezlerinden duyduğu memnuniyetten anlamlı derecede düşük olduğu bulunmuştur $(\mathrm{p}<0,01)$.

Birinci basamak sağlık hizmeti veren aile sağlığ1 merkezlerine başvuran hastaların yerleşkelere göre ortalama memnuniyet düzeyleri arasındaki farklılık incelendiğinde ise, Avrupa bölgesindeki aile sağlı̆̆ merkezlerinden hizmet alan bireylerin Anadolu bölgesinden hizmet alan bireylere göre memnuniyet puanlarının istatistiksel olarak yüksek olduğu bulunmuştur $(\mathrm{t}=2,545$; $\mathrm{p}=0,011)$. 
Tablo 3. Hasta Memnuniyetinin Demografik Özellikler ve Yerleşkeye Göre Karşılaştırılması

\begin{tabular}{|c|c|c|c|c|c|c|c|}
\hline \multicolumn{2}{|c|}{$\begin{array}{l}\text { Sosyodemografik } \\
\text { Özellikler }\end{array}$} & \multirow{2}{*}{$\frac{{ }^{n}}{205}$} & \multirow{2}{*}{$\begin{array}{r}\text { Ortalama } \\
3,5\end{array}$} & \multirow{2}{*}{\begin{aligned} & \multicolumn{1}{l}{$\begin{array}{l}\text { Standart } \\
\text { Sapma }\end{array}$} \\
& 0,7\end{aligned}} & \multirow{3}{*}{ Test İstatistiği } & \multicolumn{2}{|c|}{$\mathbf{p}$} \\
\hline \multirow{2}{*}{ Cinsiyet } & Kadın & & & & & \multirow{2}{*}{0,604} & \multirow{2}{*}{, 546} \\
\hline & Erkek & 95 & 3,4 & 0,7 & & & \\
\hline \multirow{2}{*}{$\begin{array}{l}\text { Medeni } \\
\text { Durum }\end{array}$} & Bekar & 147 & 3,4 & 0,7 & & \multirow{2}{*}{$-0,636$} & \multirow{2}{*}{0,525} \\
\hline & Evli & 253 & 3,5 & $\overline{0,7}$ & & & \\
\hline \multirow{5}{*}{$\begin{array}{l}\text { Eğitim } \\
\text { Durumu }\end{array}$} & İlkokul & 52 & 3,7 & 0,6 & & \multirow{5}{*}{2,655} & \multirow{5}{*}{$\begin{array}{r}0,033^{*} \\
\text { (1 ve } 5 \text { farkl1) }\end{array}$} \\
\hline & Ortaokul & 39 & 3,4 & 0,6 & & & \\
\hline & Lise & 131 & 3,4 & 0,8 & & & \\
\hline & Ön Lisans & 70 & 3,4 & $\overline{0,6}$ & & & \\
\hline & Lisans ve üstü & 108 & 3,4 & 0,7 & & & \\
\hline \multirow{6}{*}{$\begin{array}{l}\text { Aile } \\
\text { Sağlığı } \\
\text { Merkezi }\end{array}$} & Gaziosmanpaşa & 80 & 3,5 & 0,7 & & \multirow{6}{*}{6,458} & \multirow{6}{*}{$\begin{array}{r}\mathrm{p}<0,001 \\
\text { (6. grup } \\
\text { hepsinden } \\
\text { farkl1) }\end{array}$} \\
\hline & Eyüp & 70 & 3,4 & $\overline{0,8}$ & & & \\
\hline & Fatih & 60 & 3,7 & 0,6 & & & \\
\hline & Beykoz & 65 & 3,6 & 0,7 & & & \\
\hline & Üsküdar & 60 & 3,4 & 0,6 & & & \\
\hline & Kadıköy & 65 & 3,1 & $\overline{0,6}$ & & & \\
\hline \multirow[t]{2}{*}{ Yerleşke } & Avrupa & 210 & 3,5 & 0,7 & & \multirow[t]{2}{*}{2,545} & \multirow[t]{2}{*}{$0,011^{*}$} \\
\hline & Anadolu & 190 & 3,4 & 0,7 & & & \\
\hline
\end{tabular}

Araștırmanın sonucunda ankete katılanların yaklaşık yarısı $\% 51,3$ 'ü kadınlardan, $\% 48,8^{\prime}$ i erkeklerden oluşmaktadır. Yapılan literatür araştırmalarında; "Birinci Basamakta Hasta Memnuniyeti ve Hekim İş Doyumu İle İlişkisi" isimli çalışmada da araştırmaya katılanların \%62,6'sının, "Samsun İl Merkezinde Birinci Basamak Sağlık Hizmetlerinde Hasta Memnuniyeti" isimli çalışmada da \%59'unun ve "The General Practice Assessment Survey (GPAS): Tests of Data Quality and Measurement Properties" isimli çalışmada ise \%62,8'inin kadın olduğu görülmüștür. ${ }^{23-25}$ Türkiye İstatistik Kurumu'nun (TÜİK) 05 Mart 2021 tarihinde yayınladığ $\breve{1}_{1}$ hane halkı işgücü araştırması sonuçlarına göre; 2019 yılında, Türkiye'de 15 ve daha yukarı yaştaki istihdam edilenlerin oranı erkeklerde \%63,1 iken kadınlarda ise \%28,7 çıkmıştır. ${ }^{26}$ Buradan yola çıkarak ülkemizde çoğu kadının hem kendi hem de çocukları için aile hekimliğine daha fazla başvurduğu sonucu çıkarılabilir.

Araştırmaya katılan hastaların \%22'si 1824 yaş aralığında, \%20,8'i 25-34 yaş aralığında, \%22,8'i 35-44 yaş aralığında ve \%23,8'i 45-54 yaş aralığındadır. Medeni duruma göre araştırmanın büyük çoğunluğunu \%63,3'ünü evliler oluşturmaktadır. "Şanlıurfa İli Bozova İlçesi Merkez Sağlık Ocağına Başvuran Hastaların Sağlık Hizmetlerini Kullanma Durumu ve Etkileyen Faktörler" başlıklı araştırmada \%87'sinin, "Konya'daki Aile Hekimliği Hizmetlerinin Değerlendirilmesi" başlıklı araştırmada ise $\% 73,5^{\prime}$ inin evli olan bireylerden oluştuğu görülmüştür. ${ }^{27}$ TÜIIK' in aynı tarihte yayınladığı araştırmasındaki evlenme istatistiklerine göre; resmi olarak ilk evliliğini 2020 yılında yapmış olan kadınların ortalama evlenme yaşı 25,1 iken bu yaş erkeklerde 27,9'dur. ${ }^{26}$ Araştırmamıza katılanların çoğunluğu bu yaş aralıklarında 
olduğuna göre evli bireylerin sayının bekar bireylerin sayısından fazla olması normaldir.

Hastaların aile hekimliği hizmetleri hakkındaki görüşlerine bakıldığında en yüksek puan aldığı sorular kayıt ve bilgilerinizi gizli tutmasi $4,14 \pm 0,85$, sizi dinlemesi $3,74 \pm 0,92$ ve işini tam yapması $3,74 \pm 0,92$, en düşük aldığ1 puanlar ise doktorunuza telefonla ulaşabilmeniz $3,11 \pm 1,50$, bekleme odasında harcadığınız zaman 3,15 $\pm 1,04$ ve önceki görüşmelerde yaptıklarını ve söylediklerini bilmesi $3,27 \pm 1,03$ 'tür.

Araştırmamızda olduğu gibi Slovenya'da yapilan "An Evaluation of Patient Satisfaction With Family Practice Care in Slovenia" isimli çalışmada kayıt ve bilgilerinizi gizli tutması ve sizi dinlemesi konularında memnuniyet oranının yüksek çıktığ1 görülmüştür.28 Güney Afrika da yapılan "Interpersonal and Organizational Dimensions of Patient Satisfaction: The Moderating Effects of Health Status" isimli çalışmada ise aile hekimliklerinin gizliliğe önem verdikleri konusunda memnuniyet oranının yüksek olduğu görülmektedir. ${ }^{29}$ Ülkemizde Çankırı'da yapılan 'Çankırı'da Aile Sağlığı Merkezlerine Başvuran Bireylerin Memnuniyet Durumlarını Etkileyen Sosyo-Demografik, Çevresel ve Psikososyal Faktörlerin İncelenmesi" isimli çalışmada ise hasta bireyin dinlenmesi memnuniyet oranının en yüksek olduğu konudur. ${ }^{30}$ Aile hekimlerinin kendi kayıt ve bilgilerini gizli tuttuğuna ve kimseyle paylaşmadıklarına inanan bireylerin aile hekimlerine olan güven duygularının oluştuğu söylenebilir.

Bulgaristan'da yapilan “The EUROPEP Questionnaire For Patient's Evaluation of General Practice Care: Bulgarian Experience" isimli çalışma da bekleme odasında harcadığınız zaman konusunda memnuniyet oranlarının düşük olduğu görülmüştür. ${ }^{31}$ "Aile hekimliğinde hasta memnuniyetine yönelik bir araştırma" isimli çalışmada da telefon ile ulaşabilme ve bekleme odasinda harcanan zaman memnun olma oranının en düşük olduğu konulardır. ${ }^{32}$ Aynı zamanda Filistin'de yapılan "An evaluation of Patients opinions of primary care physicians: the use of Europep in Gaza Strip-Palestine" ve ülkemizin Adana şehrinde yapılan "Adana'daki Birinci Basamak Sağlık Kurumlarına Başvuran Hastaların Memnuniyet Düzeyleri ve $\mathrm{Bu}$ Kurumlarda Çalışan Hekimlerin İş Doyumunun Saptanması" isimli çalışmalarda da hekime telefonla ulaşabilme konusunda memnuniyet oranlarının düşük çıktığı görülmektedir. ${ }^{33,} 34$ Kişilerin aile hekimlerine telefonla ulaşmada sorun yaşamalarının nedeni, hekimlerin mesai saatleri içerisinde hem hasta muayene edip hem de telefona cevap verememesinden kaynaklıdır. Bekleme odasında harcanan zaman konusunda memnuniyet oranının düşük çıkmasının nedeni ise, birinci basamak sağlık hizmetlerinde randevu sistemi olmasına rağmen etkin kullanılmadığından kaynaklıdır. Genel olarak bakıldığında ve diğer araştırmalar ile karşılaştırıldığında ve Türkiye'nin birinci basamak sağlık hizmetlerinde yeni olduğu göz önüne alındığında memnuniyet oranının düşük olmadığ 1 hatta birinci basamak sağlık hizmetlerinden duyulan memnuniyetin sağlık hizmetlerinde meydana gelen gelişmeler ile birlikte yükseldiği görülmektedir. ${ }^{35}$ Sağlık hizmetlerinde yeni yöntemler, birinci basamak sağlık hizmetlerinde de kalite standartlarının geliştirilmesi ve akreditasyona geçilmesiyle birlikte hizmet kalitesinin giderek artması ve birinci basamak sağlık hizmetlerinden duyulan memnuniyet oranının da giderek artması beklenmektedir.

Araştırmaya katılan kişilerin yaş grubu açısından incelendiğinde 45-54 yaş arasındaki bireylerin aile hekiminden duyduğu memnuniyet oranı genç nüfusun memnuniyet oranına göre daha düşüktür. Bunun sebebinin bu nüfusun aile hekimliğini daha fazla tercih etmesi ve aile hekimine sürekli gittiği için deneyimlerinin fazla olmasından genç nüfusun ise iş, okul vb. nedenler ile aile hekimine daha az başvurmasından kaynaklanmaktadır. Araştırmamızın aksine Avustralya'da yapılan "How Do Australian Patients Rate Their General Practitioner? A Descriptive Study Using the General Practice Assessment Questionnaire" isimli çalışmada ve 
ülkemizde Edirne'de yapılan "Edirne İl Merkezinde Birinci Basamak Sağlık Kuruluşlarında Hasta Memnuniyeti ve Hekim İş Doyumu ile İlişkisinin Araştırılması" isimli çalışmada yaş arttıkça aile hekimliğinden duyulan memnuniyet oranının da arttı̆̆ı görülmüştür. ${ }^{36,37}$

Cinsiyet açısından kadınların ortalaması erkeklerden yüksektir ancak bu farklilık anlamlı bulunamamıştır. Çalışmamıza katılanların çoğunluğunun kadın olduğu kadınların erkeklere göre aile hekimliği hizmetlerine başvurma oranının da daha yüksek olduğu ortaya çıkmaktadır. "Aile Hekimliğinde Hasta Memnuniyetine Yönelik Bir Araştırma" isimli çalışmada da cinsiyet açısından anlamlı farklılık bulunamamıştır. ${ }^{20}$ "EUROPEP Aile Hekimliği Memnuniyeti Ölçeğine Göre Gümüşhane Aile Hekimliği Memnuniyet Araştırması" isimli çalışmada ise kadın hastaların memnuniyet oranının erkek hastaların memnuniyet oranına göre daha yüksek olduğu görülmüştür. ${ }^{38}$

Medeni duruma göre yapılan karşılaştırmalarda evli bireylerin ortalaması bekar bireylerden yüksektir ancak bu farklılık anlamlı bulunamamıştır. "Aile Hekimliğinde Hasta Memnuniyetine Yönelik Bir Araştırma" isimli çalışmada da cinsiyet açısından anlamlı farklılık bulunamamıştır. ${ }^{20}$ "Kayseri Devlet Hastanesi'nden Poliklinik Hizmeti Alan SSK Mensubu Erişkin Hastalarda Memnuniyet Durumu" isimli çalışmada evli olan bireylerin memnuniyet oranının bekar olan bireylerin memnuniyet oranından yüksek olduğu bulunmuştur. ${ }^{39}$ Bunun sebebi evli olan bireylerin evlilik işlemleri evlilik sonrası çocuk sahibi olma sağlık taraması, sağlık kontrolü, aşılama gibi konularda kadınların daha fazla başvurduğu ve buna bağlı olarak memnuniyet düzeyinin artmasidir.

Eğitim durumu açısından araştırmamıza katılanlar lise $\% 32,8$ ve lisans $\% 23,3$ ağırlıklıdır. Eğitim durumuna göre yapılan karşılaştırmalarda ilkokul mezunlarının memnuniyet ortalamasinın lisans ve lisansüstü mezun olan bireylerden yüksek olduğu sonucuna ulaşılmıştır. Eğitim düzeyi daha düşük olan kişilerin sadece hizmet almak amaçlı olduğu ve hizmet kalitesiyle ilgili bir beklentisinin olmadığ görülmektedir. "Edirne İl Merkezinde Birinci Basamak Sağlık Kuruluşlarında Hasta Memnuniyeti ve Hekim İş Doyumu İle İlişkisinin Araştırılması" isimli çalışmada da eğitim düzeyi düşük olan kişilerin memnuniyet oranı yüksek iken eğitim durumu yüksek olan kişilerin duydukları memnuniyet oranının beklentilerine kıyasla düşük olduğu görülmüştür. ${ }^{36}$ Eğitim durumunun artmasi ve modernleşme ile sağlık hizmetlerinden beklentilerin giderek arttığ 1 ve bu gelişmeler karşısında sunulan sağlı hizmetlerinin beklentileri karş1lamadığı görülmektedir.

İstanbul ili içerisinde bulunan Anadolu Yerleşkesi ve Avrupa Yerleşkesine göre karşılaştırmalar yapıldığında ise; Anadolu Yerleşkesi'nin memnuniyet oranının Avrupa Yerleşkesi'nin memnuniyet oranından düşük olduğu belirlenmiştir. Araştırmamıza katılanların eğitim durumlarına bakıldığında Anadolu Yerleşkesi'nin eğitim durumunun Avrupa Yerleşkesi'ne göre daha yüksek olduğu saptanmış ve beklentilerin arttığ1 sonucuna ulaşılmıştır. Daha önce İstanbul'da bu konu ile benzer bir araştırma yapılmadığ için bu madde için karşılaştırma yapılamamaktadır.

\section{SONUÇ VE ÖNERILLER}

Araştırmada İstanbul ili Avrupa Yerleşkesi'nde Gaziosmanpaşa, Eyüp, Fatih ve Anadolu Yerleşkesi'nde Beykoz, Kadıköy, Üsküdar ilçelerinde hizmet veren aile sağlı̆̆ merkezlerine başvuran hastaların medeni durumu, yaşı, eğitimi, cinsiyeti ve oturduğu yerleşke ve bölgeye göre aile hekiminin verdiği hizmetten duyduğu memnuniyet düzeyi incelenmiş ve yerleşke ve bölgeye göre değişiklik gösterdiği saptanmıştır.

Hastaların aile hekimliği ve hizmetleri hakkında memnuniyet oranlarının en yüksek olduğu konular kayıt ve bilgilerinizi gizli 
tutması, sizi dinlemesi ve işini tam yapması olarak bulunmuştur. Kayıt ve bilgilerini gizli tuttuğuna ve kimseyle paylaşmadığına inançları tam olan hastaların aile hekimlerine karşı olan güven duyguları artacaktır. Hastalar, aile hekimliği branşının tüm gerektirdiklerini, tecrübe ve bilgisiyle pekiştirerek kendisine sunduğunu ve tedaviye katıldığına inandığı aile hekimine sağlık sorunu ne olursa olsun her zaman güvenerek anlatabilecek ve tanımadığı bir hekim yerine her zaman ilk olarak aile hekimini tercih edecektir. Uygulanabilir bir sevk sisteminin oluşturulmasıyla aile hekimliği hizmetleri daha etkin olarak çalışabilecek diğer basamaklardaki hasta yığılmaları önlenecek, gereksiz tetkik ve tahlil yapılması ve gereksiz ilaç kullanımı en aza indirilmesi sağlanacaktır.

Doktorunuza telefonla ulaşabilmeniz, bekleme odasında harcadığınız zaman ve önceki görüşmelerde yaptıklarını ve söylediklerini bilmesi konuları hastaların memnuniyet oranlarının en düşük olduğu konular olarak bulunmuştur ve aşağıdaki şekilde iyileştirilebilir;

- Hastaların aile hekimlerine telefonla ulaşmada sorun yaşaması, hekimlerin mesai saatleri içerisinde hem hasta muayene edip hem de telefona cevap verememesinden kaynaklıdır. Hekimin hastalarına mail adresini vermesi; hem hastaların rahatlıkla soru sormalarını sağlayacak hem de hekimin uygun olduğu zamanda hastasının sorusunu cevaplayabilmesini sağlayacaktır. Böylelikle hizmet sürekliliğinin devamı daha da güçlenecektir.

- Hastaların bekleme odalarında geçirdikleri sürenin fazla olması randevu sisteminin etkin kullanılmadığının bir göstergesidir. Randevu sistemi ve hastaya ayrılan zaman yeniden gözden geçirilmelidir.

- Aile hekiminin hastayla olan önceki görüşmesinde yaptığı ve söylediklerini bilmesi için hekimin hastayı tanıması gerekir. Hastanın aile hekimine geliş sıklığı ne kadar az olursa aile hekiminin hastayı tanıma, söylediklerini hatırlama ve hastayı takip etme firsatı azalır. Hastalar aile hekimlerine sadece ilaç ve rapor yazdırmak için geldikleri sürece hekim ve hasta arasında olması gereken iletişim güçlenmeyecek ve hekim hastasını tanımayacaktır. Aile hekimliği hizmetlerinin etkin olarak kullanılmasını sağlamak ancak uygulanabilir ve güçlü bir sevk sistemiyle olacaktır.

45-54 yaş arasındaki bireylerin aile hekiminden duyduğu memnuniyet oranının daha düşük olduğu saptanmıştır. $\mathrm{Bu}$ yaş aralıklarında ortaya çıkan akut ve kronik hastalıklar olduğu düşünüldüğünde bu sonuç oldukça üzücüdür. $\mathrm{Bu}$ yaş aralıklarındaki hastalara daha hassas davranılmalı, akut veya kronik hastalıkları için hastalara gerekli bilgilendirmeler yapılmalı ve sağlık sorunlarıyla başa çıkmalarında aile hekimi olarak her zaman yanlarında oldukları hissettirilmelidir.

Evlilerin, bekarlara göre duyduğu memnuniyet oranının daha yüksek olduğu sonucuna varılmıştır. Evli olan bireylerin evlilik işlemleri, evlilik sonrası çocuk sahibi olma, sağlık taraması, sağlık kontrolü, aşılama gibi konularda daha fazla başvurduğu düşünüldüğünde bu hizmetlerden beklentilerin karșilandığ $\breve{g}_{1}$ sonucuna varılabilir. Bekar kişilerin çoğunlukla okuyan veya çalışan kişiler olduğu düşünüldüğünde kendilerine uygun zamanlara randevu alabilmesi konusunda zorlanacaktır. Bu konu ile ilgili çalışan kişilerinde düşünülerek hafta sonlar1 da nöbet sistemine göre aile hekimliklerinde randevu verilmesi veya hafta içi belirli saat veya günlerinde sadece çalışan kesime yönelik randevu ayarlaması yapılması gerekmektedir.

Eğitim düzeyi daha düșük olan hastaların aile hekimliğinden sadece hizmet almak amaçlı olduğu ve hizmet kalitesiyle ilgili bir beklentisinin olmadığı görülmektedir. Eğitim durumunun artması ve modernleşme ile sağlik hizmetlerinden beklentilerin giderek arttığ 1 ve bu gelişmeler karşısında sunulan aile hekimliği hizmetinin beklentileri karşılamadığ 1 görülmektedir. Memnuniyet oranının düşük olduğu doktor dışı personelin yardımı konusunda yapılabilecek iyileştirmeler beklentilerin karşılanmasında etkili olabilir. Aile sağlığı merkezinde çalışan 
tüm personele eğitim verilip standart (simüle) hasta yönteminden faydalanarak denetleyecek kişi sanki hastaymış gibi aile sağlığ merkezine gelerek personeli denetlenebilir. Uygun olan ve olmayan konuları geri bildirim yoluyla personele bildirir ve eğer gerekirse personele tekrardan eğitim verilebilir.

Aile hekimliği hizmetlerinin daha etkin, kaliteli ve hakkaniyetli olarak sunulabilmesi için uygulanabilir ve güçlü bir sevk zincirinin kurulması gerekmektedir. Öncelikle tıp okuyan öğrencilere aile hekimliğinin özendirilmesi gerekmektedir. Aile hekimliği eğitimi sürecinde birinci basamak sağlık hizmetlerinde eğitim verilebilmesi için Eğitim Aile Sağlı̆̆ Merkezi uygulaması daha çok yaygınlaştırılmalıdır.

Bireylerin birinci basamağa yönlendirilmesi amaciyla ikinci ve üçüncü basamak sağlık hizmetlerinde yaygın kullanılacak daha güçlü bir sevk zincirinin tüm bireyler tarafindan benimsetilmesi için; aile hekimliğinin olumlu taraflarını öne çıkartacak şekilde kamuoyuna bilgilendirmeler yapılabilir.
Aile hekimliği uzmanlarının eğitimleri gereği yazabilecekleri özellikle kronik hastalıkların tedavilerinde kullanılacak ilaç raporlarına ait kısıtlamalar kaldırılıp aile hekiminin sadece reçete yazan hekim gibi görülmesi önlenerek gerekli ilaç raporlarını yazabilmesi sağlanmalıdır.

Sağllğ 1 koruma ve sağllğ 1 geliştirmede önemli bir yere sahip olan sağlık eğitimi her hekimin görevidir. Ancak aile hekimliğinde hekimlerin hastalarına sadece muayene ederken belirli bilgiler vermektedirler ve bu tam olarak sağlık eğitimi olmamaktadır. Aile hekimlerinin hasta ve yakınlarına verebilecekleri eğitimler ile ilgili bir standart oluşturulmalı, tüm aile hekimleri bu konuda bilgilendirilerek hasta ve yakınlarına eğitimler bu yönde verilmelidir.

Tüm bu sonuç ve öneriler dikkate alındığında, alanında uzman aile hekimleriyle ve uygulanabilir ve güçlü bir sevk sistemiyle ülkemizdeki birinci basamak sağlık hizmetleri tamamen amacina uygun olarak çalışabilecektir.
1. Wonca, World Family Doctors. Caring For People Europe. (2011). Aile Hekimliği Avrupa Tanımı. İspanya: Türkiye Aile Hekimleri Uzmanlık Derneği Yayınları 4.

2. T.C. Sağlık Bakanlığı. (2004). Aile Hekimliğinin Tanım ve Temel İlkeleri. In: Aile Doktorları Icçin Kurs Notları (11-15). Editör P. ÜNALAN (Ed.). Ankara: Ata Ofset Tanıtım ve Matbaacılık.

3. Hayran, O. (2012). Sağlık Yönetimi Yazıları. Ankara SAGE Yayınları.

4. World Health Organization Regional Office for Europe (1998). Framework For Professional And Administrative Development Of General Practice/ Family Medicine In Europe. Copenhagen: EUR/ HFA target 28

5. T.C. Sağlık Bakanlığı. (2004). Aile Hekimliği Türkiye Modeli. Editör: S. AYDIN (Ed.). Ankara: Mavi Ofset.

6. Ak, M. (2010). "Akademik Bir Disiplin Olarak Aile Hekimliğgi”. İnönü Üniversitesi Tıp Fakültesi Dergisi, 17 (4), 403-405.

7. Starfield, B. (1988). Primary Care: Balancing Health Needs, Services and Technology. New York: Oxford University Press.

8. Ateş, M. (2013). Sağlık Hizmetleri Yönetimi. İstanbul Beta Yayıncılik.

9. Yılmaz, M. (2001). "Sağlık Bakım Kalitesinin Bir Ölçütü: Hasta Memnuniyeti”. Cumhuriyet Üniversitesi Hemşirelik Yüksekokulu Dergisi, 5 (2), 69-74.
10. Kavuncubaşı, Ş. (2000). Hastane ve Sağlık Kurumları Yönetimi. Ankara: Siyasal Kitabevi.

11. Engiz, O. (1997). Sağlık Hizmetlerinde Hasta Tatmini, In: Editör O. HAYRAN, H. SUR (Ed.). Hastane Yöneticiliği (61-87). İstanbul: Nobel Tıp Kitapevleri.

12. Alcan, Z. (1996). Bayındır Tıp Merkezi Hemşirelik Hizmetleri Müdürlüğü Hasta Memnuniyet Anket Sonuçları. In: Editör M. ÇORUH (Ed.). Sağlık Hizmetlerinde Toplam Kalite Yönetimi ve Performans Ölçümü (133-138). Ankara: Haberal Eğitim Vakfi.

13. Thomas, L.H. ve Bond, S. (1996). "Measuring Patients' Satisfaction With Nursing Care". Journal of Advanced Nursing, 23 (4), 747-756. https://doi.org/10.1111/j.13652648.1992.tb01818.x

14. Özer, A. ve Çakıl, E. (2007). "Sağlık Hizmetlerinde Hasta Memnuniyetini Etkileyen Faktörler". T1p Araştırmaları Dergisi, 5 (3), 141-142.

15. Karadağ, Z. (2007). Aile Hekimliği Uygulamasının Müşteri-Hasta Memnuniyetine Etkisi. (Yüksek Lisans Tezi), Gazi Üniversitesi Sosyal Bilimler Enstitüsü, Ankara.

16. Crane, J.A. (1997). "Patient Comprehension of Doctor Patient Communication on Discharge Fromthe Emergency Department”. J Emerg Med, 15 (1), 1-7. 
17. Akdeniz, M, Ungan, M. ve Yaman, H. (2010). "Aile Hekimliği: Çağdaş Bir Sağlık Hizmeti Sunma Biçimi”. Gerofam, Kanita Dayalı, Hakemli, Gerontoloji Yönelimli Aile Hekimliği Dergisi, 1 (1), 19-20.

18. Yaman, H, Akdeniz, M. ve Howe, J. (2010). "Gerofam Kavramı: Önümüzdeki Demografik Değișime Yönelik Bir Çözüm Önerisi”. Gerofam, Kanıta Dayalı, Hakemli, Gerontoloji Yönelimli Aile Hekimliği Dergisi, 1 (1), 114.

19. Ardahan, M, Arabacı, Z. ve Saka, M.C. (2018). "Bir Aile Sağlığı Merkezine Başvuran Hastaların Memnuniye Düzeyleri ve Etkileyen Faktörler". Sosyal Politika Çalışmaları Dergisi, (40), 53-70.

20. Kırılmaz, H. ve Öztürk, K. (2018). "Aile Hekimliğinde Hasta Memnuniyetine Yönelik Bir Araştırma”. Sağlık Akademisyenleri Dergisi, 5 (1), 60-70.

21. Aktürk, Z, Dağdeviren, N, Şahin, E.M, Özer, C, Yaman, H, Göktaş O, Filiz, T.M, Topsever, P, Onganer, E, Aydın, S, Yarıș, F. ve Maraș, İ. (2002). "Hastalar Hekimleri Değerlendiriyor: Europep Ölçeği”. Dokuz Eylül Üniversitesi Tıp Fakültesi Dergisi, 16 (3), 153 160.

22. Son Kalaycı, Ş. (2010). SPSS Uygulamalı Çok Değişkenli İstatistik Teknikleri (Vol. 5). Ankara: Asil Yayın Dağıtım.

23. Turgu, S, Öztora, S, Çaylan, A. ve Dağdeviren, H.N. (2018). "Birinci Basamakta Hasta Memnuniyeti ve Hekim İş Doyumu ile İlişkisi”. Türkiye Aile Hekimliği Dergisi, 22 (2), 78-91.

24. Sünter, A.T, Dabak, S, Canbaz, S. ve Pekșen, Y. (2003) "Samsun İl Merkezinde Birinci Basamak Sağlık Hizmetlerinde Hasta Memnuniyeti". Ondokuz May1s Üniversitesi Tıp Dergisi, 20 (3), 135-139.

25. Ramsay, J, Camphell, J.L, Schroter, S, Green, J. and Roland, M. (2000). "The General Practice Assessment Survey (GPAS): Tests of Data Quality and Measurement Properties”. FamPract, 17 (5), 372-379.

26. Türkiye İstatistik Kurumu (TÜİK). (2021) "İstatistiklerle Kadın, 2020". Erişim adresi: https://tuikweb.tuik.gov.tr/PreHaberBultenleri.do?id=37 221 (Erişim tarihi: 25.03.2021).

27. Akıllı, A. ve Genç, M. (2007). "Şanlıurfa İli Bozova İlçesi Merkez Sağlık Ocağına Başvuran Hastaların Sağlik Hizmetlerini Kullanma Durumu ve Etkileyen Faktörler”. İnönü Üniversitesi Tıp Fakültesi Dergisi, 14 (2), 95-99.

28. Kersnik, J. (2000). "An Evaluation of Patient Satisfaction With Family Practice Care In Slovenia”. Int J Qual Health Care, 12 (2), 143-7.

29. Westaway, M.S, Rheeder, P, Van Zyl, D.G. and Seager J.R. (2003). "Inter Personal and Organizational Dimensions of Patient Satisfaction: The Moderating Effects of Health Status". Int J Qual Health Care, 15 (4), 337-344.

30. Özaras, G. ve Dil, S. (2012). “Çankırı'da Aile Sağlığı Merkezlerine Başvuran Bireylerin Memnuniye Durumlarını Etkileyen Sosyo-Demografik, Çevresel ve Psikososyal Faktörlerin İncelenmesi”. Çankırı Karatekin Üniversitesi Sosyal Bilimler Enstitüsü Dergisi, 6 (2), 389-404.

31. Dimova, R, Stoyanova, R. and Keskinova, D. (2017). "The EUROPEP Questionnaire For Patient's Evaluation of General Practice Care: Bulgarian Experience". Croat Med J, 58 (1), 63-74.

32. Kırılmaz, H. ve Öztürk, K. (2018). "Aile Hekimliğinde Hasta Memnuniyetine Yönelik Bir Araştırma”. Sağlık Akademisyenleri Dergisi, 5 (1), 60-70.
33. Abu Mourad, T, Shashaa, S, Markaki, A, Alegakis, A, Lionis, C. and Philalithis, A. (2007). "An Evaluation of Patients Opinions of Primary Care Physicians: The Use of Europep In Gaza Strip-Palestine”. J Med Syst, 31 (6), 497-503.

34. Akpınar, E. (2010). Adana'daki Birinci Basamak Sağlık Kurumlarına Başvuran Hastaların Memnuniyet Düzeyleri ve Bu Kurumlarda Çalışan Hekimlerin İş Doyumunun Saptanması. (Uzmanlık Tezi), Cukurova Üniversitesi Tıp Fakültesi Aile Hekimliği Anabilim Dalı, Adana.

35. Baltacı, D, Kara, İ.H, Bahçebaşı, T, Sayın, S, Yılmaz, A. ve Çeler, A. (2011). "Düzce İlinde Birinci Basamakta Sağlık Hizmeti Alan Hastaların Aile Hekimi ve Muayenehanesi Hakkındaki Görüşlerinin Belirlenmesi: Pilot Çalıșma”. Konuralp Tıp Dergisi, 3 (2), 9- 15.

36. Turgu, S. (2012). Edirne İl Merkezinde Birinci Basamak Sağlık Kuruluşlarında Hasta Memnuniyeti ve Hekim İş Doyumu ile Illişkisinin Araştırılması. (Uzmanlık Tezi), Trakya Üniversitesi Tıp Fakültesi Aile Hekimliği Anabilim Dalı, Edirne.

37. Potiriadis, M, Chondros, P, Gilchrist, G, Hegarty, K, Blashki, G. and Gunn, J.M. (2008). "How Do Australian Patients Rate Their General Practitioner? A Descriptive Study Using The General Practice Assessment Questionnaire”. Med J Aust, 189 (4), 215-219.

38. Bostan, S. ve Havvatoğlu, K. (2014). "Europep Aile Hekimliği Memnuniyeti Ölçeğine Göre Gümüşhane Aile Hekimliği Memnuniyet Araştırması”. Gümüşhane Üniversitesi Sağlık Bilimleri Dergisi, 3 (4), 1067-1078.

39. Ünalan, D, Öztürk, A, Tolga, Y, Taşdelen, C, Yazlak, Z, Öğüt, E, Gündüz, E. ve Elmalı, F. (2008). "Kayseri Devlet Hastanesi'nden Poliklinik Hizmeti Alan SSK Mensubu Erişkin Hastalarda Memnuniyet”. Fırat Sağlık Hizmetleri Dergisi, 3 (8), 85-98. 